\title{
The Effect of the Realistic Mathematic Education (RME) Learning Model On Students' Mathematical Problem Solving Abilities : A Meta-Analysis
}

\author{
${ }^{1}$ Habib Ratu Perwira Negara, ${ }^{2}$ Malik Ibrahim, ${ }^{3}$ Kiki Riska Ayu Kurniawati, ${ }^{4}$ Anisa \\ Firdaus, ${ }^{5}$ Risma Maulidina ${ }^{6}$ Muhammad Saifudin \\ ${ }^{1}$ Universitasa Bumigora, ${ }^{2}$ Universitas Nahdaltul Ulama NTB, ${ }^{3456}$ Universitas Islam Negeri Mataram \\ 1'habib.ratu27@gmail.com, ${ }^{2}$ malikedu.org@gmail.com, ${ }^{3}$ kikirak27@uinmataram.ac.id, \\ 19190103065.mhs@uinmataram.ac.id, ${ }^{5}$ 190103066.mhs@uinmataram.ac.id, \\ 6190103067.mhs@uinmataram.ac.id
}

\section{ARTICLE INFO}

\section{Article History:}

Received : 14-04-2021

Revised : 05-05-2021

Accepted : 06-05-2021

Online : 06-05-2021

Keywords:

Realistic Mathematic

Education (RME);

Problem Solving;

Meta-Analysis

\begin{abstract}
Abstract: Realistic Mathematics Education (RME) learning is a learning approach that uses contextual issues and student-focused learning. This study aims to find out the huge influence of the Realistic Mathematics education learning model on students' mathematical problem-solving skills. The research method used is a meta-analysis with the help of JASP software by collecting data from the results of research indexed indexer databases such as Google Scholar, SINTA, and Garuda Portal. The data were taken in accordance with the criteria of inclusion and exclusion of this study to then be determined by the value of effect size (ES) and standard error (SE). The results of the data analysis using JASP software showed that realistic mathematics education (RME) learning model on mathematical problem-solving skills of students as a whole has a positive influence which is obtained by estimation (ES) of 0.71 or $71 \%$ based on RE Models with high category, as well as the p-value (egger's test) of 0.121 which means no publication is indicated bias, as well as the results of moderator variable analysis on classification per education level. This means that realistic Mathematics Education (RME) learning model for students' mathematical problem-solving skills can be said to be appropriate if used for students, especially in junior high and elementary school level.
\end{abstract}

Abstrak: Pembelajaran Realistic Mathematic Education (RME) ini merupakan pendekatan pembelajaran yang menggunakan masalah kontekstual, dan pembelajaran terfokus pada siswa. Penelitian ini bertujuan untuk mengetahui besar pengaruh model pembelajaran Realistic Mathematic education terhadap kemampuan pemecahan masalah matematis siswa. Metode penelitian yang digunakan adalah meta-analisis dengan bantuan software JASP yaitu dengan cara mengumpulkan data dari hasil-hasil penelitian yang terindeks database pengindeks seperti Google Scholar, SINTA, dan Portal Garuda. Data yang diambil sesuai kriteria inklusi dan ekslusi penelitian ini untuk kemudian ditentukan nilai effect size (ES) dan standard error (SE). Hasil analisis data menggunakan software JASP menunjukkan bahwa model pembelajaran Realistic Mathematics Education (RME) terhadap Kemampun Pemecahan Masalah Matematis Siswa secara keseluruhan pengaruhnya positif yang dimana di dapatan nilai Estimasi (ES) sebesar 0.71 atau $71 \%$ berdasarkan RE Models dengan kategori tinggi, serta nilai p-value (egger's test) sebesar 0.121 yang berarti tidak terindikasi publication bias,begitu juga dengan hasil analisis variabel moderator pada klasifikasi per jenjang pendidikan. Ini berarti model pembelajaran Realistic Mahematics Education (RME) terhadap Kemampuan Pemecahan Masalah matematis Siswa bisa dikatakan sudah tepat jika digunakan untuk Peserta didik terutama pada jenjang SMP dan SD. 


\section{A. LATAR BELAKANG}

Pendidikan merupakan sistem proses perubahan menuju pendewasaan, pencerdasan dan pematangan diri. Dengan kegiatan tersebut diharapkan mampu mengubah dan mengembangkan diri menjadi semakin dewasa, cerdas dan matang. Hal ini sesuai dengan isi Undang-Undang No. 20 Tahun 2003 tentang Sistem Pendidikan Nasional yang menyatakan bahwa pendidikan adalah usaha sadar dan terencana untuk mewujudkan suasana belajar dan proses pembelajaran agar peserta didik secara aktif mengembangkan potensi dirinya untuk memiliki kekuatan spiritual keagamaan, pengendalian diri, kepribadian, kecerdasan, akhlak mulia, serta keterampilan yang diperlukan dirinya dan masyarakat (RI, 2003).

Hal di atas dapat dikembangkan melalui pembelajaran matematika, karena kemampuan-kemampuan tersebut tidak lain adalah merupakan tujuan dari pelajaran matematika itu sendiri sebagaimana yang dinyatakan oleh Pusat Kurikulum. Tujuan umum pembelajaran matematika sekolah adalah (1) melatih cara berpikir dan bernalar dalam menarik kesimpulan, misalnya melalui kegiatan penyelidikan, eksplorasi, eksperimen, menunjukkan kesamaan, perbedaan, konsisten, dan inkonsistensi, (2) mengembangkan aktivitas kreatif yang melibatkan imajinasi, intuisi dan penemuan dengan mengembangkan pemikiran divergen, orisinal, rasa ingin tahu, membuat prediksi dan dugaan, serta mencoba-coba, (3) mengembangkan kemampuan pemecahan masalah dan, (4) mengembangkan kemampuan menyampaikan informasi atau mengkomunikasikan gagasan antara lain melalui pembicaraan lisan, catatan, grafik, peta, diagram, dan menjelaskan gagasan. Harapannya siswa dapat menguasai konsep dasar matematika secara benar sehingga dapat menerapkannya dalam kehidupan sehari-hari. Lebih jauh pembelajaran matematika di jenjang Sekolah Menengah Pertama diharapkan dapat mengembangkan kemampuan matematika dan meningkatkan kemampuan memecahkan masalah. Kemampuan pemecahan masalah merupakan hal yang penting dalam pelajaran matematika.

Kemampuan pemecahan masalah berhungungan dengan kemampuan siswa untuk membaca, memahami bahasa soal cerita, menyajikan dalam model matematika, merencanakan perhitungan berdasarkan model matematika tersebut, serta menyelesaikan perhitungan dari soal-soal yang tidak rutin. Ada empat tahapan dalam memecahkan masalah menurut Polya yaitu memahami masalah, menyusun rencana pemecahan masalah, melaksanakan rencana penyelesaian atas masalah, dan memeriksa kembali proses dan hasil.

Banyaknya peserta didik yang berpikiran bahwa matematika merupakan mata pelajaran yang sulit karena keabstrakan konsepnya, sedangkan daya pikir siswa masih berfikir secara konkret, dimana daya abstrak belum berkembang secara optimal. Sehingga banyak dari mereka ketika kegiatan pembelajaran matematika berlangsung hanya duduk mendengarkan, lalu mencatat karena dalam pembelajaran matematika berlangsung masih terfokus hanya pada gurunya saja. Harusnya pembelajaran matematika berlangsung secara alami, dimana siswa bisa langsung menerapkan berdarkan situasi dilingkungan yang pernah mereka alami, sehingga siswa akan belajar menemukan sendiri pengetahuannya dengan tetap ada arah dan bimbingan dari guru. Menemukan kembali artinya guru tidak mengajarkanya akan tetapi siswa harus berusaha menemukannya sendiri. Untuk itu siswa harus dibiasakan dan dilatih untuk berfikir secara mandiri, sehingga diharapkan dapat tumbuhkan kemampuan-kemampuan yang lebih bermanfaat untuk mengatasi masalah-masalah yang akan dihadapi siswa dimasa depan. Salah satu model pembelajaran yang dapat digunakan dalam pembelajaran matematika adalah model pembelajaran Realistic Mathematics Education (RME). 
Pembelajaran Realistic Mathematics Education (RME) merupakan model pembelajaran matematika yang dilaksanakan dengan menempatkan realistik dan pengalaman siswa sebagai titik awal pembelajaran. Masalah-masalah realistik digunakan sebagai sumber munculnya konsep-konsep matematika atau pengetahuan matematika informal.

Berdasarkan pemikiran di atas, maka peneliti merasa tertarik untuk melakukan research terkait Pengaruh Model Pembelajaran RME Terhadap Kemampuan Pemecahan Masalah Matematis Siswa dimana pendidik membutuhkan informasi yang akurat untuk mediator yang mungkin mempengaruhi ukuran efek studi. Penelitian ini dilakukan dengan tujuan untuk mengungkap efek keseluruhan studi individu tentang RME dan menganalisis variabel mediator sehingga dapat mempertimbangkan hasilnya untuk implementasi RME lebih lanjut.

\section{B. METODE PENELITIAN}

Metode penelitian ini menggunakan metode meta-analisis dengan mengkaji beberapa artikel dari tahun 2010 sampai dengan tahun 2020. Hasil pencarian di Google Scholar ditemukan sebanyak 24.800 artikel yang berkaitan dengan kata kunci Model Pembelajaran RME terhadap Kemampuan Pemecahan Masalah Matematis Siswa. Meta analisis bersifat kuantitatif karena menggunakan perhitungan angka-angka dan statistik untuk kepentingan praktis yang tak mungkin untuk dilakukan dengan metode lain.

Dalam penelitian ini memiliki beberapa prosedur yang akan dilakukan untuk memperoleh hasil atau data dengan tahapan-tahapan sebagai berikut:

1. Mempelajari kata kunci yang akan digunakan pada penelitian,

2. Melakukan pencarian literatur dengan menggunakan google scholar, SINTA, dan Portal Garuda,

3. Mendowload File PDF yang sesuai dengan kata kunci,

4. Mengambil beberapa sampel data dari PDF seperti nama pengarang, tahun terbit jurnal, jumlah siswa (N), nilai uji fisher (F), uji students (t), dan uji korelasi (r),

5. Mengkonverensi nilai $\mathrm{F}$ dan $\mathrm{t}$ ke nilai $\mathrm{r}$ dengan menggunakan rumus:

$$
\begin{aligned}
& \mathrm{F}=t^{2}, \\
& \mathrm{t}=\sqrt{F}, \\
& \mathrm{r}=\frac{t}{\sqrt{t^{2+N-2}}}
\end{aligned}
$$

6. Menghitung nilai effect size (ES) dan standar error (SE) menggunakan rumus :

$$
\begin{aligned}
& z=E S=0,5 \times \ln \frac{1+r}{1-r}, \\
& S E=\sqrt{\frac{1}{N-3}}
\end{aligned}
$$

7. Melakukan analisis data dengan menggunakan software JASP,

8. melakukan interpretasi terhadap hasil analisis atau output dari software JASP,

9. Menganalisis hasil-hasil yang ditemukan dari artikel-artikel yang menjadi rujukan data,

10. Terakhir, mengambil kesimpulan dari hasil penelitian meta-analysis 


\section{HASIL DAN PEMBAHASAN}

\section{Hasil}

Hasil penelusuran diperoleh data publikasi yang memenuhi sebanyak 31 publikasi. Data yang dikumpulkan dalam penelitian ini adalah nilai uji Fisher (F), uji student ( $\mathrm{t}$ ), uji korelasi (r), dan jumlah subjek penelitian (N). Sedangkan metode atau media pembelajaran, serta jenjang dapat digunakan pada proses pembahasan atau analisis data lanjutan dengan ketentuan tambahan tertentu. Berikut adalah tabel 1 hasil konveksi nilai $\mathrm{F}$ dan $\mathrm{t}$ ke nilai $\mathrm{r}$ serta tabel 2 konveksi nilai $\mathrm{r}$ ke ES dan SE.

Tabel 1. Data Penelitian dan Hasil Konversi Nilai F dan t ke r

\begin{tabular}{|c|c|c|c|c|c|c|c|}
\hline No & Nama Penulis, Tahun & Jenjang & Mapel & $\mathrm{N}$ & f-hitung & t-hitung & r-hitung \\
\hline 1 & Rosyada, 2019 & SD & Matematika & 53 & & 2,091 & 0,281000974 \\
\hline 2 & Susanti, 2018 & SMP & Matematika & 40 & & 2,835 & 0,417828918 \\
\hline 3 & Noviyana, 2019 & SMP & Matematika & 48 & & 8,11 & 0,767103826 \\
\hline 4 & Susanti, 2017 & MTS & Matematika & 62 & & & 0,037 \\
\hline 5 & Wulandari, 2020 & SD & Matematika & 50 & & 13,3 & 0,886883487 \\
\hline 6 & Asih, 2019 & SD & Matematika & 34 & & 12,358 & 0,909266181 \\
\hline 7 & Septian, 2014 & SMP & Matematika & 83 & & 1,707 & 0,186344552 \\
\hline 8 & Susana, 2014 & SMP & Matematika & 44 & & 2,83 & 0,400186823 \\
\hline 9 & Rista, 2020 & SMA & Matematika & 48 & & 2,189 & 0,307149136 \\
\hline 10 & Nopriyanti, 2019 & SMK & Matematika & 48 & & 2,693 & 0,369034846 \\
\hline 11 & Amaliyah, 2020 & SD & Matematika & 40 & & 10,0707 & 0,85290111 \\
\hline 12 & Andini, 2019 & MTS & Matematika & 31 & & 5,771 & 0,731124896 \\
\hline 13 & Ermawati, 2020 & SD & Matematika & 50 & & 6,167 & 0,664881454 \\
\hline 14 & Yudha, 2019 & SMP & Matematika & 34 & & 6,8 & 0,768766574 \\
\hline 15 & Refianti, 2020 & SMP & Matematika & 23 & & 3,45 & 0,601457086 \\
\hline 16 & Anisa, 2014 & SMP & Matematika & 128 & & 5,94 & 0,467725815 \\
\hline 17 & Destini, 2019 & SD & Matematika & 60 & & 2,085 & 0,264056885 \\
\hline 18 & Sarbiyono, 2016 & MAN & Matematika & 80 & & 2,264 & 0,248318328 \\
\hline 19 & Lisa, 2019 & SMP & Matematika & 105 & & 7,705 & 0,604677385 \\
\hline 20 & Primayani, 2019 & SMA & Matematika & 68 & & & 0,61 \\
\hline 21 & Salsabilla, 2020 & SMP & Matematika & 48 & & 3,4125 & 0,449460209 \\
\hline 22 & Maulida, 2015 & MAN & Peluang & 51 & & 2,44 & 0,329148403 \\
\hline 23 & Agustina, 2018 & SMP & Matematika & 49 & & 7,693 & 0,74656869 \\
\hline 24 & Harahap, 2019 & SMP & Matematika & 153 & & 7,573 & 0,524651431 \\
\hline 25 & Halim, 2019 & SMP & Matematika & 50 & 203,686 & 14,2718604 & 0,899603343 \\
\hline 26 & Muttaqin, 2010 & SMP & Matematika & 66 & 7,216 & $-1,622$ & $-0,19870695$ \\
\hline 27 & Sulianto, 2013 & SD & Matematika & 38 & & 0,971 & 0,159754862 \\
\hline 28 & Logo, 2020 & SMP & Matematika & 30 & & $-17,576$ & $-0,95754539$ \\
\hline 29 & Samosir, 2017 & SMP & Matematika & 29 & & $-0,3369$ & $-0,06470058$ \\
\hline 30 & Simamora, 2020 & SMP & Aljabar & 30 & 2,441 & 3,84 & 0,587334505 \\
\hline 31 & Ria, 2018 & SMP & Matematika & 63 & & 3,682 & 0,426421615 \\
\hline
\end{tabular}


Tabel 2. Data Penelitian dan Hasil Konversi ke ES dan SE

\begin{tabular}{clrr}
\hline No & \multicolumn{1}{c}{ Nama Penulis, Tahun } & ES & SE \\
\hline 1 & Rosyada, 2019 & 0.172212878 & 0.141421356 \\
\hline 2 & Susanti, 2018 & 0.299848946 & 0.164398987 \\
\hline 3 & Noviyana, 2019 & 1.222308509 & 0.149071198 \\
\hline 4 & Susanti, 2017 & 0.01886393 & 0.130188911 \\
\hline 5 & Wulandari, 2020 & 2.806515609 & 0.145864991 \\
\hline 6 & Asih, 2010 & 3.563825338 & 0.179605302 \\
\hline 7 & Pratama, 2014 & 0.105005611 & 0.111803399 \\
\hline 8 & Pratama, 2014 & 0.280592096 & 0.156173762 \\
\hline 9 & Rista, 2020 & 0.193294508 & 0.149071198 \\
\hline 10 & Nopriyanti, 2019 & 0.24890915 & 0.149071198 \\
\hline 11 & Amaliyah, 2020 & 2.096387596 & 0.164398987 \\
\hline 12 & Andini, 2019 & 1.02049505 & 0.188982237 \\
\hline 13 & Ermawati, 2020 & 0.760557612 & 0.145864991 \\
\hline 14 & Yudha, 2019 & 1.23313152 & 0.179605302 \\
\hline 15 & Refianti, 2020 & 0.590794464 & 0.223606798 \\
\hline 16 & Anisa, 2014 & 0.360447819 & 0.089442719 \\
\hline 17 & Destini, 2019 & 0.159201366 & 0.132453236 \\
\hline 18 & Sarbiono, 2016 & 0.147534067 & 0.113960576 \\
\hline 19 & Lisa, 2020 & 0.598147832 & 0.099014754 \\
\hline 20 & Primayani, 2019 & 0.61055664 & 0.124034735 \\
\hline 21 & Salsabilla, 2020 & 0.337115703 & 0.149071198 \\
\hline 22 & Maulida, 2015 & 0.212072566 & 0.144337567 \\
\hline 23 & Agustina, 2018 & 1.100205645 & 0.147441956 \\
\hline 24 & Harahap, 2019 & 0.443638459 & 0.081649658 \\
\hline 25 & Halim, 2019 & 3.195550101 & 0.145864991 \\
\hline 26 & Muttaqin, 2010 & 0.202700974 & 0.125988158 \\
\hline 27 & Sulianto, 2019 & 0.088193701 & 0.169030851 \\
\hline 28 & Logo, 2020 & -0.806959526 & 0.19245009 \\
\hline 29 & Samosir, 2017 & -031411916 & 0.196116135 \\
\hline 30 & Simamora, 2020 & 0.559843509 & 0.19245009 \\
\hline 31 & Ria, 2018 & 0.129099445 \\
\hline & & & \\
\hline
\end{tabular}

\section{Pembahasan}

Selanjutnya, penulis melakukan uji hipotesis dan uji publication bias terhadap data yang sudah diperoleh. Dalam meta-analisis menggunakan software JASP yang dilihat dalam penarikan kesimpulan adalah nilai $z$ dan $p$-value pada tabel Coefficients. Adapun hipotesis sebagai berikut.

\section{Uji hipotesis}

$H_{0}$ : true effect size $=0 \quad$ Medel pembelajaran Realistic Mathematic Education (RME) tidak berpengaruh terhadap kemampuan pemecahan masalah peserta didik. 
$H_{1}:$ true effect size $\neq 0 \quad$ Model pembelajar Realistic Mathematic Education (RME) berpengaruh terhadap kemampuan pemecahan masalah peserta didik.

$H_{0}:$ true effect size $=0$

Uji publikasi bias

$H_{1}:$ true effect size $\neq 0$

Data sampel terindikasi publication bias

Data sampel tidak terindikasi publication bias

Berdasarkan hasil simulasi diperoleh output JASP sebagai berikut.

a) Uji Hipotesis

Uji hipotesis dapat dilihat berdasarkan nilai $z$ dan $p$-value pada tabel output JASP sesuai Tabel 3.

Tabel 3. Output JAPS Coefficient

\section{Coefficients}

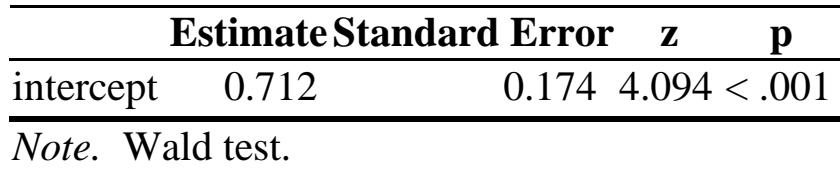

Pada Tabel 3. tentang coefficients di atas, terlihat nilai $z$ sebesar 4.094 dan nilai $p$-value sebesar 0,001 yang berarti lebih kecil dari nilai signifikansi $5 \%(0,05)$. Ini berarti hipotesis $H_{0}$ ditolak, dalam hal ini true effect size tidak sama dengan 0 , dengan kata lain pembelajaran dengan metode Realistic Mathematics Educaation (RME) ini berpengaruh signifikan terhadap kemampuan pemecahan masalah matematis siswa. Adapaun sebaran effect size untuk setiap studi disajikan pada gambar 1 di bawah ini,
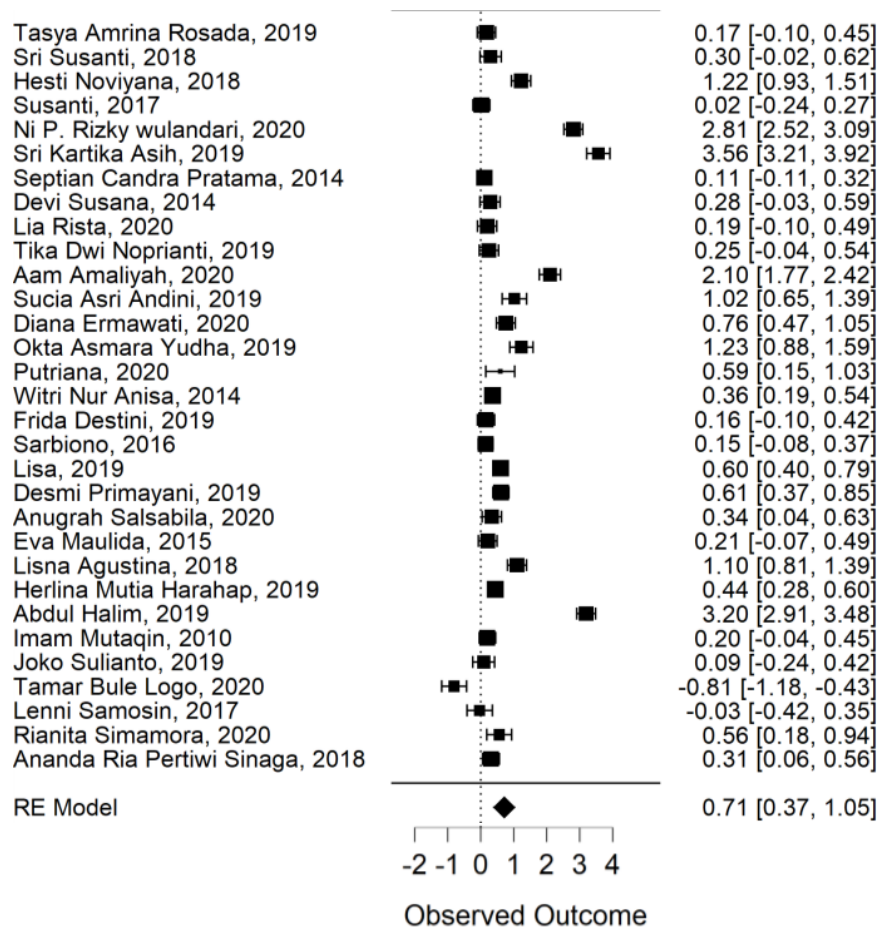

Gambar 1. Trim and Fill 
Berdasarkan hasil ploting publikasi pada Gambar 1. Diperoleh nilai summary effect atau RE Model sebesar 0,71 dengan kata lain pengaruh pembelajaran dengan Model RME terhadap Kemampun Pemecahan Masalah Matematis Siswa sebesar $71 \%$, sedangkan $29 \%$ dipengaruhi oleh factor yang lain.

b) Uji Publication Bias

Uji ini dilakukan untuk melihat apakah data yang sudah terkumpul dapat dijadikan sampel yang representative dari populasinya. Uji ini dapat dilihat menggunakan nilai pada output Regression Method, Fail-Safe $N$ dan Forest Plot.

\section{1) Rank Correlation dan Regression Method}

Tabel 4. Regression Test

Regression test for Funnel plot asymmetry ("Egger's test")

\begin{tabular}{lll}
\hline \multicolumn{2}{c}{$\mathbf{z}$} & \multicolumn{2}{c}{$\mathbf{p}$} \\
\hline sei & 0.713 & 0.476 \\
\hline
\end{tabular}

Pada Tabel 4. terlihat nilai $z$ yang merupakan besarnya koefisien regresi sebesar 0,713 , sedangkan nilai $p$-value sebesar 0,476 lebih besar dari nilai signifikan $5 \%(0,05)$, dalam hal ini true effect size tidak sama dengan 0 , Hal ini yang menunjukkan bahwa hipotesis $H_{0}$ diterima dengan kata lain tidak terindikasi publication bias.

2) Fail-Safe $N$

Tabel 5. File Drawer Analysis

File Drawer Analysis

\section{Fail-safe NTarget Significance Observed Significance}

\begin{tabular}{llll}
\hline Rosenthal & 8082.000 & 0.050 & $<.001$ \\
\hline
\end{tabular}

Tabel 5. menunjukkan seberapa banyak penelitian yang memiliki ratarata effect size sama dengan 0 yang harus ditambahkan ke dalam sampel penelitian agar hasil penelitian terbebas dari publication bias. Berdasarkan Tabel 5. di atas terlihat nilai Fail-safe $N$ sebesar 8082.000 hasil publikasi yang harus ditambahkan. Nilai ini tidak menjadi wajib jika berdasarkan hasil Rank Correlation dan Regression Method sudah tidak terindikasi publication bias. Disamping itu untuk menguji publication bias dapat dilakukan dengan ketentuan jika $\mathrm{N}>5 \mathrm{~K}+10$ ( $\mathrm{K}=$ Jumlah studi), maka dapat disimpulkan bahwa tidak terdapat bias publikasi. Dari tabel 6 . diperoleh $8082.000>5 \times 31+10 \approx 8082.000>165$. Jadi sampel yang digunakan dalam penelitian ini terindikasi tidak adanya publication bias. 
3) Forest Plot

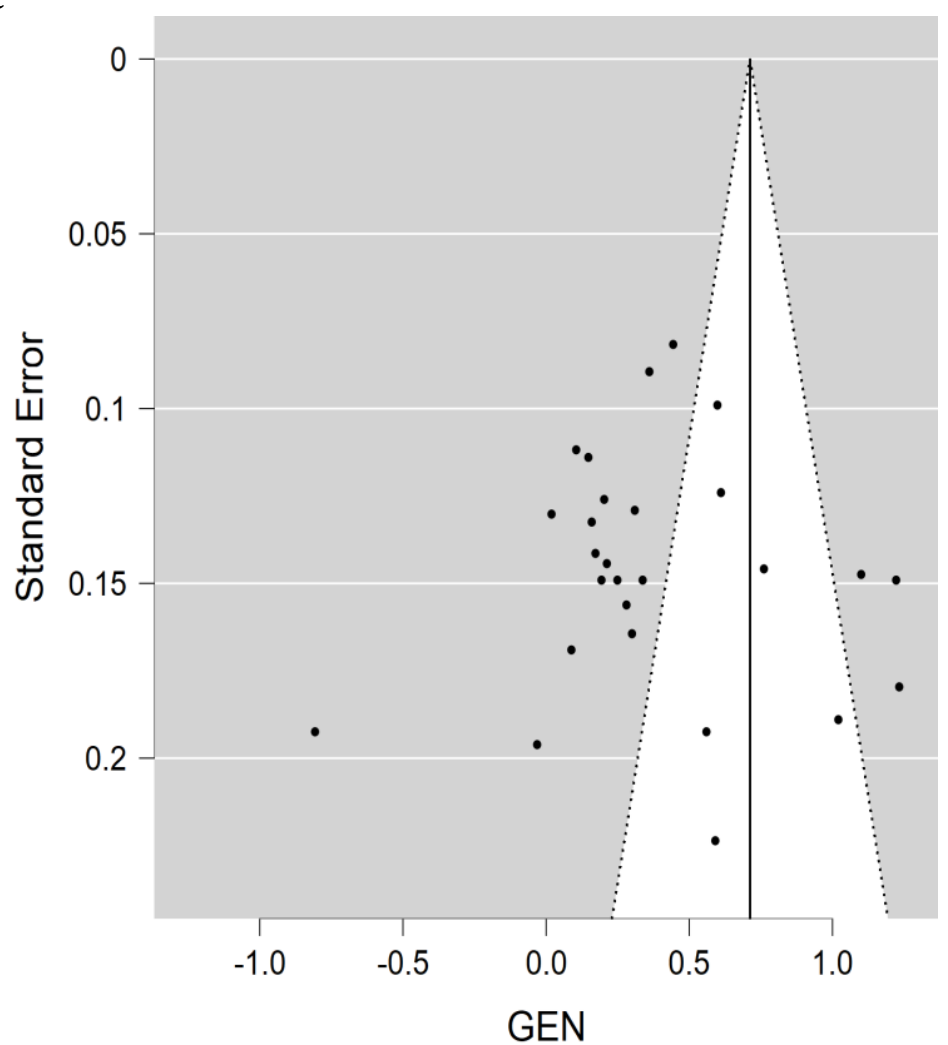

Gambar 2. Forest Plot

Berdasarkan hasil ploting publikasi pada Gambar 2. dapat diketahui bahwa tidak ada penelitian yang hilang yang ditandai lingkaran terbuka, seluruh lingkaran tertutup dan sebaran data tidak membentuk pola tertentu. Hasil ini menunjukkan sampel yang digunakan dalam penelitian ini terindikasi tidak adanya publication bias.

\section{c) Variabel Moderator}

Analisis variabel moderator diperlukan untuk melihat pengaruh pada jenjang pendidikan dan mata pelajaran. Adapun hasil analisis data menggunakan JASP sesuai tabel 6 berikut:

Tabel 6. Variabel Moderator

\begin{tabular}{ccccccc}
\hline No & Kategori & Estimate & $\mathrm{Z}$ & p-value (egger's test) & $\begin{array}{c}\text { RE } \\
\text { Models }\end{array}$ & Kategori \\
\hline 1 & SMA & 0.287 & -0.389 & 0.697 & 0.29 & Rendah \\
\hline 2 & SMP & 0.582 & -0.008 & 0.994 & 0.58 & Sedang \\
\hline 3 & SD & 1.376 & 1.428 & 0.153 & 1.38 & Tinggi \\
\hline
\end{tabular}

Berdasarkan hasil uji hipotesis dan uji bias yang sudah kami lakukan tentang model pembelajaran RME terhadap Kemampuaan Pemecahan Masalah matematis siswa, pada jenjang SMA, SMP, dan SD ternyata ada yang berpengaruh dan tidak berpengaruh, yang dimana hasil analisis untuk jenjang SMA terhadap pengaruh model pembelajaran RME memuat nilai Estimasi (ES) sebesar 0,29 atau 29\% berdasarkan RE Models dengan kategori rendah sehingga menimbulkan dampak positif, serta nilai p-value (egger's test) sebesar 0.697 yang berarti tidak terindikasi publication bias. 
Pada jenjang SMP pengaruhnyapun menimbulkan dampak positif atau bisa dikatakan berpengaruh jika di lakukan model pembelajaran dengan model RME memuat nilai Estimasi (ES) sebesar 0,58 atau 58\% berdasarkan RE Models dengan kategori sedang, serta nilai p-value (egger's test) sebesar 0.994 yang berarti tidak terindikasi publication bias. Pada jenjang SD pengaruhnya sangat positif atau lebih berpengaruh bagi peserta didik pada jenjang SD dimana memuat nilai Estimasi (ES) sebesar 1.38 dengan kategori tinggi sehingga menimbulkan dampak positif, serta nilai p-value (egger's test) sebesar 0.153 yang berarti tidak terindikasi publication bias. Hal ini berarti implementasi model pembelajaran Realistic Mahematics Education (RME) terhadap Kemampuan Pemecahan Masalah matematis Siswa bisa dikatakan sudah tepat jika digunakan untuk Peserta didik terutama pada jenjang SMP dan SD.

\section{SIMPULAN DAN SARAN}

Berdasarkan hasil uji hipotesis dan uji bias yang sudah kami lakukan terhadap artikel dengan kata kunci pengaruh metode Realistic Mathematics Education terhadap Kemampun Pemecahan Masalah Matematis Siswa. Jadi bisa disimpulkan dari data yang sudah dipaparkan bahwa model pembelajaran Realistic Mathematics Education (RME) terhadap Kemampun Pemecahan Masalah Matematis Siswa secara keseluruhan pengaruhnya positif yang dimana di dapatan nilai Estimasi (ES) sebesar 0.71 atau 71\% berdasarkan RE Models dengan kategori tinggi, serta nilai p-value (egger's test) sebesar 0.121 yang berarti tidak terindikasi publication bias, begitu juga dengan hasil analisis variabel moderator pada klasifikasi per jenjang pendidikan. Ini berarti model pembelajaran Realistic Mahematics Education (RME) terhadap Kemampuan Pemecahan Masalah matematis Siswa bisa dikatakan sudah tepat jika digunakan untuk Peserta didik terutama pada jenjang SMP dan SD.

\section{REFERENSI}

Agustina, L., Sormin, Azizah, S., \& Sahara, N. (2018). Peningkatan Kemampuan Pemecahan Masalah Matematika Siswa Melalui Pendekatan Matematika Realistik (PMR) di Kelas VII SMP NEGERI 4 Sipirok. 3(2007), 55-64.

Agustina, L., Sormin, M. A., \& Sahara, N. (2018). Peningkatkan Kemampuan Pemecahan Masalah Matematika Siswa Melalui Pendekatan Matematika Realistik (Pmr) Di Kelas Vii Smp Negeri 4 Sipirok. 3(1), 2598-2400.

Amaliyah, A. (2020a). Pengaruh Model Pembelajaran Realistic Mathematics Education (RME) Terhadap Kemampuan Pemecahan Masalah Matematika. JTIEE, 4(2), 1-8.

Amaliyah, A. (2020b). Pengaruh Model Pembelajaran Realistic Mathematics Education (Rme) Terhadap Kemampuan Penalaran Matematis Siswa. Seminar Nasional Pendidikan Matematika 2018, 04(2), 19-29.

Andini, Sucia, A., \& Harleni, S. (2019). Pengaruh Pendekatan Matematika Realistik (Pmr) Terhadap Kemampuan Pemecahan Masalah Matematika Siswa Kelas Viii MTs AlAzhar Bulu Cina Tahun Pelajaran 2017/2018. Jurnal Serunai Matematika, 11(2), 110115.

Andini, S. A. (2019). Pengaruh Pendekatan Matematika Realistik (PMR) Terhadap Kemampuan Pemecahan Masalah Matematika Siswa Kelas VIII MTS AL-Azhar Bulu Cina Tahun Pelajaran 2017/2018. Journal of Chemical Information and Modeling, 
11(2), 1689-1699.

Anisa, W. N. (2014). Peningkatan Kemampuan Pemecahan Masalah Dan Komunikasi Matematik Melalui Pembelajaran Pendidikan Matematika Realistik Untuk Siswa SMP Negeri Di Kabupaten Garut. Jurnal Pendidikan Dan Keguruan, 1(1).

Asih, S. K. (2010). Keefektifan Model Pembelajaran Realistic Mathematics Education ( Rme ) Terhadap. TSCJ, 2(2), 103-110.

Destini, Firda. (2019). Penggunaan Pendekatan RME terhadap Kemampuan Pemecahan Masalah. 1, 288-297.

Destini, Frida. (2019). Penggunaan Pendekatan RME Terhadap Kemampuan Pemecahan Masalah Siswa. 1, 288-297.

Ermawati, D. (2020a). PEMECAHAN MASALAH MATEMATIS SISWA SD. 1-9.

Ermawati, D. (2020b). Pengaruh Pendekatan PMRI Terhadap Kemampuan Pemecahan Masalah Matematis Siswa SD. Journal Pendidikan Dasar, 1-9.

Halim, A., Asmin, \& Ahyaningsih, F. (2019). Pengaruh Pendekatan Matematika Realistik Terhadap Kemampuan Berfikir Kreatif Dan Pemecahan Masalah Matematika Siswa Kelas VII. PARADIKMA JURNAL PENDIDIKAN MATEMATIKA, 12, 1-9.

Harahap, H. M., \& Lubis, R. (2019). Efektivitas Pendekatan Pembelajaran Matematika Realistik ( Pmr) Terhadap Kemampuan Pemecahan Masalah Matematis Siswa SMP Negeri 7. 2(2), 105-113.

Hesti Noviyana, D. F. U. (2019). Prosiding Seminar Nasional Matematika dan Pendidikan Matematika Sesiomadika. Prosiding Sesiomadika, 2(1c), 829.

Lisa. (2019). Penerapan Pembelajaran Matematika Realistik Untuk Meningkatkan Kemampuan Pemecahan Masalah Matematis Siswa SMP Negeri 8 Lhokseumawe. Logaritma: Jurnal Ilmu-Ilmu Pendidikan Dan Sains, 03(01), 41-54. https://doi.org/10.24952/logaritma.v8i01.2355

Lisa. (2020). Penerapan Pembelajaran Matematika Realistik Untuk Meningkatkan Kemampuan Pemecahan Masalah Matematis Siswa SMP Negeri 8 Lhokseumawe. Prosiding Seminar Nasional Integrasi Matematika Dan Nilai Islami, 3(1), 363-372.

Logo, T. B., Rowa, Y. R., \& Uskono, I. V. (2020). Pengaruh Model Pembelajaran Matematika Realistik Terhadap Kemampuan Pemecahan Masalah Matematika Siswa SMP. ASIMTOT: JURNAL KEPENDIDIKAN MATEMATIKA, 2(1).

Maulida, E., Kasmini, L., \& Novita, R. (2015). Peningkatan Kemampuan Pemecahan Masalah Melalui Pendekatan Matematika Realistik Pada Materi Peluang. II(April), 132-143.

Model, P., Matematika, P., Terhadap, R., Pemecahan, K., Matematika, M., Smp, S., Effect, T. H. E., Realistic, O. F., Learning, M., On, M., Ability, T. H. E., Math, S., \& Of, P. (2020). Tamar Bule Logo 1 , Yohana Rinna Rowa 2 , Irmina Veronika Uskono 3. 2(1).

Muttaqin, I. (2010a). Eksperimentasi Realistic Mathematics Education (RME) terhadap Kemampuan Pemecahan Masalah pada Materi Segiempat dan Segitiga Ditinjau dari Motivasi Belajar Siswa Kelas VII SMP Kabupaten Gunungkidul Tahun Pelajaran 2009/2010. Tesis.

Muttaqin, I. (2010b). Peningkatan Kemampuan Pemecahan Masalah Dan SelfEsteem Siswa Melalui Pembelajaran Humanistik Berbasis Pendidikan Matematika Realistik.

Nopriyanti, T D, Erlina, M., \& Andinasari. (2019). Pengaruh Model Pembelajaran Realistic Mathematic Education Terhadap Kemampuan Pemecahan Masalah Matematis Siswa SMK PGRI 2 Palembang. Seminar Nasional Pendidikan Program Pascasarjana, 687695.

Nopriyanti, Tika Dwi, \& Erlina, M. (2019). Pengaruh Model Pembelajaran Realisticmathematic Education ( Rme) Terhadap Kemampuan Pemecahan Masalah 
Matematis Siswa SMK PGRI 2 Palembang.

Noviyana, H., \& Fitriani, D. (2019). Pengaruh Model Realistic Mathematics Education (Rme) Terhadap Kemampuan Pemecahan Masalah Matematis Siswa Kelas VIII SMP. Prosiding Sesiomadika, 2(1c), 829.

Pratama, S. C., Masi, L., \& Rosdiana. (2014a). Efektivitas Pembelajaran Matematika Realistik Terhadap Kemampuan Pemecahan Masalah Matematika Pada Siswa Kelas VIII SMP Negeri 4 Kendari. Jurnal Penelitian Pendidikan Matematika, 5(1), 99-113.

Pratama, S. C., Masi, L., \& Rosdiana. (2014b). Jurnal Penelitian Pendidikan Matematika Volume 5 No. 1 Januari 2017. 2(2), 99-113.

Primayani, D., \& Mardianti. (2019). Pengaruh Pendekatan Matematika Realistik ( PMR ) Terhadap Kemampuan Pemecahan Masalah Matematika Siswa Kelas X SMA Negeri 2 Binjai Tahun Pelajaran 2018/2019. Jurnal Serunai Ilmu Pendidikan, 5(1), 90-94.

Primayani, D., \& Mardiati, M. (2019). Pengaruh Pendekatan Matematika Realistik (Pmr) Terhadap Kemampuan Pemecahan Masalah Matematika Siswa Kelas X Sma Negeri 2 Binjai Tahun Pelajaran 2018/2019. Serunai : Jurnal Ilmiah Ilmu Pendidikan, 5(1), 9094. https://doi.org/10.37755/sjip.v5i1.161

Putriana, Refianti, R., \& Rosalina, E. (2020). KEMAMPUAN PEMECAHAN MASALAH MATEMATIS SISWA KELAS VIII SMP MENGGUNAKAN PENDEKATAN MATEMATIKA REALISTIK INDONESIA. 3(1), 45-51.

Realistik, M., \& Materi, P. (2015). yaitu 2,44 > 1,67, dengan demikian H. II(April), 132-143. RI, U. U. (2003). UU No 20 Tahun 2003 Tentang Sistem Pendidikan Nasional pada Pasal. In Kemendiknas.

Ria, A. S. P. (2018). Efektivitas Pembelajaran Matematika Realistik Terhadap Kemampuan Pemecahan Masalah Matematik Siswa Kelas VII SMP. Cartesius: Jurnal Pendidikan Matematika, 1(1), 1-9.

Rista, L., Eviyanti, C. Y., \& Matematika, P. (2020). Peningkatan Kemampuan Pemecahan Masalah Dan Self Esteem Siswa Melalui Pembelajaran Humanistik Berbasis Pendidikan Matematika Realistik. Jurnal Cendekia: Jurnal Pendidikan Matematika, 04(02), 1153-1163.

Rosyada, T. A., Sari, Y., \& Cahyaningtyas, A. P. (2019). Pengaruh Model Pembelajaran Realistic Mathematics Education (Rme) Terhadap Kemampuan Pemecahan Masalah Matematika Siswa Kelas V. Jurnal Ilmiah Pendidikan Dasar, 6(2), 116. https://doi.org/10.30659/pendas.6.2.116-23

Salsabilla, A. (2020). Implementasi Pendekatan Pendidikan Matematika Realistik Indonesia (PMRI) Untuk Meningkatkan Kemampuan Pemecahan Masalah Siswa. 01(01), 9-12.

Samosir, L., \& Saragih, R. F. (2017). Peningkatan Kemampuan Pemecahan Masalah Matematika Siswa Melalui Pendekatan Matematika Realistik ( PMR ). Semnastika Unimed, 107-111.

Sarbiono. (2016). Penerapan Pendekatan Matematika Realistik Terhadap Kemampuan Pemecahan Masalah Matematis Siswa. Jurnal Review Pembelajaran Matematika, 1(2), 163-173.

Sarbiyono. (2016). Penerapan Pendekatan Matematika Realistik Terhadap Kemampuan Pemecahan Masalah Matematis Siswa. JPMI Uurnal Pembelajaran Matematika Inovatif), 1(5), 949. https://doi.org/10.22460/jpmi.v1i5.p949-956

Simamora, R. (2020). Model Realistic Mathematic Education ditinjau dari Aspek Kemampuan Pemecahan Masalah Aljabar. Jurnal Math Educator Nusantara ( JMEN ), 6, 22-29.

Simamora, R., Studi, P., Matematika, P., \& Medan, K. (2020). Model Realistic Mathematic Education Ditinjau Dari Aspek Kemampuan Pemecahan Masalah Aljabar. 6, 22-29. 
Sulianto, J., \& Prabowo, K. E. (2019). Implementasi Pembelajaran Rme ( Realistic Mathematic Education) Terhadap Penalaran Dan Kemampuan Memecahkan Masalah Matematika Siswa Kelas V SDN Karangayu 02 Semarang. 3(1), 1-5.

Sulianto, J., \& Prabowo, K. eko. (2013). Implementasi Pembelajaran RME ( Realistic Mathematic Educarion) Terhadap Penalaran dan Kemampuan Memecahkan Masalah Matematika Siswa Kelas V SDN Karangayu 02 Semarang. 03(02), 1-5.

Susana, D. (2014). Basic_calculation_Al\#29L. 17.

Susanti. (2017). Meningkatkan Kemampuan Pemecahan Masalah Matematis dan SelfEfficacy Siswa MTs Melalui Pendekatan Pendidikan Matematika Realistik. Suska $\begin{array}{llll}\text { Journal of } & \text { Mathematics }\end{array}$ https://doi.org/10.24014/sjme.v3i2.4148

Susanti, S., \& Nurfitriyanti, M. (2018). Pengaruh Model Realistic Mathematics Education (RME) Terhadap Kemampuan Pemecahan Masalah Matematika Pada Siswa Kelas VII SMPN 154 Jakarta. JKPM (Jurnal Kajian Pendidikan Matematika), 3(2), 115. https://doi.org/10.30998/jkpm.v3i2.2260

Wulandari, N. P. R., Dantes, N., \& Antara, P. A. (2020). Pendekatan Pendidikan Matematika Realistik Berbasis Open Ended Terhadap Kemampuan Pemecahan Masalah Matematika Siswa. Jurnal Ilmiah Sekolah Dasar, 4(2), 131. https://doi.org/10.23887/jisd.v4i2.25103

Yudha, O. A., Rosmaiyadi, \& Nurhayati. (2019a). Pengaruh Model MEA dengan Pendekatan RME terhadap Kemampuan Pemecahan Masalah Pada Materi Perbandingan Kelas VII. Journal Of Educational Review and Research, 2(1), 46-54.

Yudha, O. A., Rosmaiyadi, R., \& Nurhayati, N. (2019b). Pengaruh Model MEA dengan Pendekatan RME terhadap Kemampuan Pemecahan Masalah Pada Materi Perbandingan Kelas VII. Journal of Educational Review and Research, 2(1), 46. https://doi.org/10.26737/jerr.v2i1.1852 